\title{
POLYPHARMACY IN ELDERLY PATIENTS AND THEIR PROBLEMS
}

\author{
SITI FAUZIYAH ${ }^{1,2}$, MAKSUM RADJI ${ }^{1 *}$, RETNOSARI ANDRAJATI $^{1}$
}

${ }^{1}$ Department of Pharmacy, Faculty of Pharmacy, University of Indonesia, Depok, 16424, Indonesia. ${ }^{2}$ Department of Pharmacy, Dr. Mintohardjo Naval Hospital, Jakarta 10210, Indonesia. Email: maksumradji@gmail.com

Received: 18 March 2017, Revised and Accepted: 20 April 2017

ABSTRACT

Aging and diseases associated with aging is a condition associated with old age. An important approach to maintaining health status and physical examination in geriatric patients is very important, including nutrition problems, sight, hearing, urine containment, balance and fall prevention, osteoporosis, and polypharmacy. The use of polypharmacy will give some impact on the elderly, including increasing the improper treatment, adverse drug reactions (ADRs), and some of the problems that affect the changing nature of the pharmacokinetics and pharmacodynamics of drugs. Aging in the elderly with some illness, may potentially lead to get more number of medicines, leading to inappropriate prescribing patterns, and contributing to adverse drug reactions and hospitalization. This review will describe the effect of polypharmacy in elderly patients.

Keywords: Polypharmacy, Adverse drug reactions, Drug-drug interactions, Elderly, Inappropriate medication.

(C) 2017 The Authors. Published by Innovare Academic Sciences Pvt Ltd. This is an open access article under the CC BY license (http://creativecommons. org/licenses/by/4. 0/) DOI: http://dx.doi.org/10.22159/ajpcr.2017.v10i7.18548

\section{INTRODUCTION}

Health development is directed to increase awareness, willingness, and ability of healthy life for everyone to improve the health of as high as can be realized. The impact of the success of health development characterized by rising life expectancy, lowered mortality rate and the birth mother [1]. According to the Central Bureau of Statistics Indonesia in 2013, life expectancy in Indonesia is 73 years for women and men is 69 years. National Development Planning Agency projected life expectancy in Indonesia in 2025 may reach 73.6 years [2]

In the United States, the elderly population aged over 65 years to reach $13 \%$ of the total population, but total consumption of drugs accounted for $33 \%$ of all prescriptions. In 2040, 25\% of Americans are expected to consume the drug reaches $50 \%$ of all prescriptions. While in Singapore, in 2030 the elderly population is projected to $18.4 \%$ of the total population in Singapore [3]

The pattern of prescribing for someone with multiple diseases must be based on the best available evidence. The use of polypharmacy will give some impact on the elderly, including an increase in inappropriate treatment, adverse drug events (ADEs), and some of the problems that are affected by changes in pharmacokinetics, pharmacodynamics, and comorbidities. Polypharmacy is defined as at least one of the administrations of medicinal drugs are not indicated [4]. This definition requires an assessment of the drug and drug compliance were used. Providing a drug with an incorrect indication, drug duplication, will contribute to polypharmacy. For example, a proton-pump inhibitor used as prophylaxis in hospitalized patients to prevent stress ulcers. If the treatment is continued when the patient was discharged from the hospital, then this drug would be considered unnecessary given because there was no indication. Polypharmacy associated with significant consequences such as side effects, noncompliance drug use, and drug interactions (DIs), as well as an increased risk of geriatric syndromes [5]. Polypharmacy also contributes to the accumulation of the drug in the elderly, resulting in serious side effects of drugs [6]. Various studies indicate potentially inappropriate medication (PIM) is caused by polypharmacy. Thus, this review will evaluate the impact of polypharmacy in the elderly, and PIMs.

\section{POPULATOIN OF ELDERLY}

United States defines the elderly as individuals who have 65-74 years of age, who have health problems and diseases, dependence on others as well as the problems the function and dysfunction of organs, while a very old age is an individual over the age of 85 years (the "oldest old" $>85$ years). According to statistical data, the geriatric population and the elderly will continue to increase, this increase will continue with a significant amount. The population in 2004 was 36.2 million and increase to 46.2 million in 2014, reaching up to $28 \%$. When projected in the year 2060 will reach 98.2 million. Meanwhile, people who are older than 85 years has reached 6.2 million in 2014, will increase continuously and is projected to be 14.6 million in 2040 [7]. In Germany, the elderly population and which has very old has reached 4, 5 million people, and $5.4 \%$ were aged 80 years or more. This population will continue to grow in the past decade. In Italy, they were very elderly ( $>85$ years of age) is growing rapidly. Increased life expectancy and improving health in the elderly is an indicator of a country's success in prevention of various diseases associated with the aging process [8]. The elderly aged 60 years and older is increasing rapidly. In 2010, the world's population aged 60 and over was $11 \%$ and in 2030, will reach up to $16 \%$. In 2030 , Europe has been estimated that the percentage of the population aged 60 will reach up to $29 \%$. They have special problems due to aging, changes in physiological functions, some diseases of the elderly, which can cause various health problems. As a result, the elderly will consume more drugs or polypharmacy, which can lead to serious risks and complications [9].

The increasing of health and welfare of the population will have an effect on the increase in life expectancy in Indonesia. According to the Indonesian Central Bureau of Statistics, it is estimated that in 2035 there are five provinces with the percentage of the population 65 years and over were highest at 14.9\%, Central Java, East Java, 14.1\%, 14.0\% Yogyakarta, Bali $12.1 \%$, and North Sulawesi $12.0 \%$. Thus, the number of people 65 years and over in the province has reached more than $10 \%$ of the total estimated population of Indonesia in 2035 amounted to 305 million people). The older population in 2035 is predicted to reach $15.77 \%$ [2].

\section{CHANGE OF AGING}

Aging is a multidimensional process. Normal aging and diseases associated with aging is an integral condition. Typically, the aging 
process will lower physiological functions, for example; decreased bone density, osteoarthritis, and suffering cataract lens, while the diseases associated with old age, but does not occur in all people (aging probabilistic) is dementia, hypothyroidism, stroke, and congestive heart failure (CHF). Various studies of modern molecular and cellular biology have demonstrated the mechanism of aging, such as DNA damage, oxidative materials, free radical, catastrophic error, the aging process, apoptosis, immune, neuroendocrine, and others. Decrease integrative cell with a specific function (pituitary, thyroid, adrenal, pancreas, and glands gonads) cause abnormalities of homeostasis. Decreased organ function in the elderly is more prone to various diseases so that the elderly will receive many medications (polypharmacy) $[10,11]$.

Androgens and anabolic growth hormones are hormones that contribute to the formation of muscle mass and strength, as we age, these hormones also decrease, so that people will lose strength, muscle mass, and muscle weakness [12]. Aging, clinically can be attributed to weakness in the muscles, fractures occur more easily, and a decrease in body mass index results in falls, trauma, infection, the risk of delirium, unstable blood pressure, and deterioration of other physical conditions [13]. Table 1 is an example of a physical examination of the elderly.

Being elderly is a lifelong process that cannot be avoided. It is a process of change of the physical, mental, and social. The success of health development and life cycle approach that starts from a mother preparing her pregnancy until the baby is born, toddlers, school-age children and adolescents, adults, and pre-elderly, will determine the quantity and the quality of life and health of the elderly in the future. If the health services at all stages of the life cycle are done well, it can be ascertained that the quality of life in the elderly will be good [15]. Individual treatment plans should be done by considering each drug pharmacokinetics and pharmacodynamics profile in certain patients because the drug can have different reactions in different patients, a specific profile should be developed for each patient. Aspects of this profile may include the following [16]:

- The medicine will give the pharmacokinetics and pharmacodynamics profile in certain patients

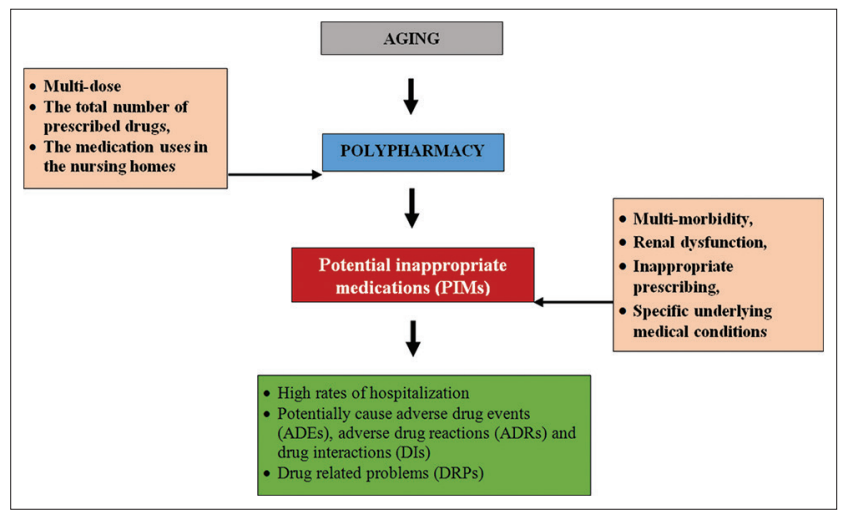

Fig. 1: The impact caused by polypharmacy

Table 1: Summary of age-related changes in muscle [14]

\begin{tabular}{l}
\hline Reduction in muscle mass (30-40\%) \\
Decreased myosin heavy chain synthesis \\
Decrease in force \\
Infiltration of fat into muscle tissue \\
Increased fatigability \\
Decrease in basal metabolic rate (decrease up to $4 \%$ of decade, after \\
50 -year-old) \\
Decreased innervations \\
Increased number of myofibril per motor unit \\
Loss or reduced proliferation of satellite cells \\
Shift toward Type I fibers
\end{tabular}

- The potential DIs in certain patients

- The potential for adverse drug reactions (ADRs) in certain patients

- The issue of patient adherence to pharmacotherapy plan.

\section{MULTI DISEASES}

Pathophysiology of the elderly should be assessed in an integrated manner by a health professional collaboration. A series of the disease, before and during treatment, family and social history, and demographic data need to be examined to assess the health of the elderly through geriatric assessment. Approach to medical records and physical examination in any very specific geriatric patient, including nutrition problems, sight, hearing, urine containment, balance and fall prevention, osteoporosis, and polypharmacy should be a concern in the treatment of the elderly [17]. The severity of the disease that accompanies the aging process in the elderly should be a concern for health professionals in assessing their condition. Table 2 provides an overview of the relationship between symptoms, diseases, and organ disorders.

\section{THE IMPACT CAUSED BY POLYPHARMACY}

In general, elderly people suffer from some chronic diseases, consequently using a drug that is more complex than other groups of age [20]. This group has a condition more severe disease than younger adults, due to changes in pharmacokinetics and pharmacodynamics in the elderly may affect the metabolism of drugs and drug side effects. Often the drugs used in the elderly are often inaccurate, which would be associated with health problems, including the incidence of drug side effects, and ADRs. Drugs given to the elderly need to be assessed on all aspects of elderly patients, taking account of comorbidity, complex treatment regimens, functional and cognitive status, the goals of therapy, and quality of life. A comprehensive evaluation is needed to improve the compliance of drug use in elderly patients were included, prescribing the wrong drug without indication, an indication without drugs [21].

- Wrong prescription is related to the prescription indication that led to a significantly increased risk of reaction/event associated with a drug that is not needed, such as incorrect medication dosage, treatment duration and method of use, as well as the clinical effects, including interactions with medicines drug or drug-disease

- Drugs without indication associated with prescription drugs that are not in accordance with the patient's clinical condition or medications used for clinical treatment, but they are used to prevent or prophylaxis against certain other diseases

- Indication without prescription relating to drugs clinical need, but not given. The impact of polypharmacy in elderly patients as shown in Fig. 1.

Association between polypharmacy and ADEs/ADRs

Multimorbidity and polypharmacy generally will increase the risk of ADR. ADR will be difficult to avoid having to consider the treatment of patients with possible inappropriate prescribing and potential risk in the elderly. Another reason, pharmacokinetic properties may change in elderly patients so that the dose needs to be adjusted to avoid the incidence of drug side effects [22]. The prevalence of polypharmacy, inappropriate prescriptions and ADR interlinked, therefore, should be assessed to adjust the drug is needed, so that a given drug needs to pay attention to patient safety in elderly patients [23]. The incidence rate of polypharmacy, inappropriate prescriptions, and ADR are interrelated. The improvement in the quality of the prescription, the selection of the appropriate doses, avoids drug-DIs (DDIs), can reduce ADEs. An appropriate of prescribing is the key issue to improving drug safety in the elderly [24].

Frequent of inappropriate prescription can lead to the risk of falling in elderly patients. It is also associated with polypharmacy [25]. Besides, to avoid the side effects of medication, dosage, formulation, and administration need to be adjusted according to the age and condition of the patient, even some certain medication use should be avoided [26]. Polypharmacy in elderly patients in Singapore showed that the 
Table 2: Review of system organ in elderly $[18,19]$

\begin{tabular}{|c|c|c|}
\hline System & Symptoms & Possible problems \\
\hline Visual & $\begin{array}{l}\text { Loss of near vision (presbyopia) } \\
\text { Loss of central vision } \\
\text { Loss of peripheral vision } \\
\text { Glare from lights at night } \\
\text { Eye pain }\end{array}$ & $\begin{array}{l}\text { Common with age macular degeneration glaucoma, stroke } \\
\text { cataracts glaucoma, temporal arteritis }\end{array}$ \\
\hline Auditory & $\begin{array}{l}\text { Hearing loss } \\
\text { Loss of high-frequency range (presbycusis) }\end{array}$ & $\begin{array}{l}\text { Acoustic neuroma, cerumen, Paget's disease, drug-induced } \\
\text { ototoxicity common with age }\end{array}$ \\
\hline Cardiovascular & $\begin{array}{l}\text { Difficulty eating or sleeping, over-fatigue, shortness of } \\
\text { breath, orthopnea }\end{array}$ & $\mathrm{CHF}$ \\
\hline Pulmonary & Chronic cough, shortness of breath & Chronic obstructive pulmonary disease \\
\hline Gastrointestinal & $\begin{array}{l}\text { Constipation } \\
\text { Fecal incontinence }\end{array}$ & $\begin{array}{l}\text { Chronic obstructive pulmonary disease hypothyroidism, } \\
\text { dehydration, hypokalemia, colorectal cancer, inadequate } \\
\text { fiber, inactivity, drugs fecal impaction, rectal carcinoma }\end{array}$ \\
\hline Genitourinary & $\begin{array}{l}\text { Urinary frequency, hesitancy } \\
\text { Urinary incontinence }\end{array}$ & BPH estrogen deficiency, detrusor instability \\
\hline Neurologic/psychiatric & $\begin{array}{l}\text { Syncope } \\
\text { Transient loss of power, sensation or speech } \\
\text { Persistent aphasia or dysarthria disturbance of gait } \\
\text { insomnia } \\
\text { Loss of memory extremities }\end{array}$ & $\begin{array}{l}\text { Postural hypotension, seizure, cardiac dysrhythmia, aortic } \\
\text { stenosis, hypoglycemia transient ischemic attack stroke } \\
\text { Parkinson's disease, stroke circadian rhythm disturbance, } \\
\text { drugs, sleep apnea, mood disorder Alzheimer's disease, } \\
\text { multi-infarct dementia }\end{array}$ \\
\hline Extremities & $\begin{array}{l}\text { Leg and foot swelling } \\
\text { Leg pain }\end{array}$ & $\begin{array}{l}\text { Osteoarthritis, radiculopathy, intermittent claudication, } \\
\text { night cramps CHF, venous insufficiency }\end{array}$ \\
\hline
\end{tabular}

BPH: Benign prostatic hyperplasia, CHF: Congestive heart failure

prevalence of the risk of drug-related problems (DRPs) is strongly influenced by the numbers of medication received by elderly patients, as well as these have the potential risk of occurrence of side effects of drugs, and even become one of the causes of the increase of the elderly treated in the emergency room in hospital [27]. In a retrospective study of the elderly population reported that use of the drug two or three types, the potential occurrence of DDIs. Elderly patients who received treatment with five or more types of drugs have the potential risk of DIs is 4 times greater [28]. Polypharmacy was found to be a significant predictor of DDIs-related ADR. The incidence of DDI-related ADRs in elderly outpatients was increased with the patient's age, number of diagnosed diseases, and number of drugs consumed [29].

\section{Association between polypharmacy and DRPs}

Calderón-Larrañaga et al. [30] suggest that the effect of age on ADEs might disappear when the variable level of multimorbidity is considered, and the occurrence of ADEs should also take into consideration of polypharmacy, include medications administered at a hospital or over-the-counter drugs [30]. The chronic health conditions and high medication consumption and inadequate drug therapy led to various DRPs, particularly related to the patient safety, which caused other health problems [31]. Abdullah Al-Hamid and others reported that the cardiovascular diseases (CVDs) comprised chronic conditions, which required multiple medicine regimens (or polypharmacy), and this contributed to DRPs. The hospitalization rate had a higher prevalence in patients admitted due to DRPs (12.1\%) than patients admitted due to ADRs (7\%) and ADEs (4.6\%). The most DRPs were encountered among adult patients admitted with CVDs and diabetes. The main causes of hospitalization due to old age and polypharmacy were highly represented among patients admitted to hospitals due to DRPs [32].

A polypharmacy, non-compliance, and prescription errors were underlying reasons for developing DRPs. A few studies classified DRPs based on severity and preventability. Few studies classified DRPs based on severity and preventability. They reported that the cost for the management of DRP was directly proportional to severity. A hospital should bring down therapy cost incurred to treat DRP admissions to a greater extent (Table 3) [33].
Table 3: Categories of DRPs [3]

\begin{tabular}{ll}
\hline Problem & Description \\
\hline $\begin{array}{l}\text { Drug use without } \\
\text { indication }\end{array}$ & $\begin{array}{l}\text { The patient get a drug for treatment no } \\
\text { needed for medically indication } \\
\text { The patient has a medical problem that is } \\
\text { the result of an ADR or adverse effect } \\
\text { The patient has a medical problem by the } \\
\text { resulting of DDI or drug-disease interaction } \\
\text { The patient receive too much or too little } \\
\text { of the necessary drug from the clinical } \\
\text { indicated } \\
\text { sub-therapeutic dose }\end{array}$ \\
$\begin{array}{l}\text { The patient receive some drug treatment } \\
\text { for longer period of time than clinically } \\
\text { treatment }\end{array}$ & $\begin{array}{l}\text { indicated } \\
\text { The patient has a medical problem that } \\
\text { requires drug therapy but is not receiving a } \\
\text { drug for that condition }\end{array}$ \\
Untreated condition & $\begin{array}{l}\text { Use of a drug which is contraindicated for } \\
\text { the patient because of existing medical } \\
\text { problems }\end{array}$ \\
Clinical & $\begin{array}{l}\text { Use of multiple drugs with similar } \\
\text { pharmacological effect when single drug is } \\
\text { adequate }\end{array}$ \\
contraindication &
\end{tabular}

\section{Associated between polypharmacy and PIMs}

Polypharmacy is the biggest problem that contributed to the incident PIMs, caused to hospitalization, ADEs, particularly among the elderly, because of changes in the body's response and their multimorbidity. The greatest risk factor for the elderly is polypharmacy, which is associated with drug-related problems, such as adverse effects, poor adherence to drug use, DDIs or drug-disease interactions, and the high risk of the syndrome geriatric. Polypharmacy is also defined as at least one drug delivery a type of medicine there is no clinical indication [34]. Below is a describing of correlation polypharmacy in geriatric patients. The age of 65 years (elderly), often accompanied by multi-pathology of chronic diseases, such as hypertension, diabetes, osteoporosis, heart disease, and other degenerative diseases, as it 
also issues of independence and dependence properties, function and dysfunction of organs. Aging is a multidimensional process. Normal aging and diseases associated with aging are two separate conditions. Associated with the normal aging processes that decrease in physiological functions in living organisms, for example, bone loss, osteoarthritis, and cataracts. Diseases associated with aging, but not caused by aging and do not occur in all people (including probabilistic aging) including dementia, hypothyroidism, stroke, and CHF [10]. Administration of drugs in elderly individuals should take into account the physiological changes due to aging patients where there would be changes in the pharmacokinetics (absorption, distribution, metabolism, and excretion) and pharmacodynamics (drug action against target) [6,35,36].

- Multi-dose is an alternative to ordinary prescription dispensing for people with regular medication use combined with difficulties in handling and administering their drugs [37]

- Multi-dose users may be more exposed to potentially inappropriate drug use than ordinary prescription users

- However, multi-dose users seem to have a lower probability of potentially serious DIs
- Younger elderly with multi-dose drug dispensing may have the most problems with potentially inappropriate drug use (Table 4).

\section{CONCLUSION}

Polypharmacy in elderly patients is often difficult to avoid because it is associated with a number of diseases suffered by the elderly. Therefore, inappropriate prescribing is an important concern of health workers to avoid unwanted drug effects.

Administration of drugs in the elderly should pay attention to the pharmacokinetics and pharmacodynamics of drugs especially the adjustment of drug dose to avoid drug side effects and DIs. Elderly patients were given five or more medications, need to be closely monitored because they are four times higher risk of undesired effects due to DIs. The role of pharmacists in assessing polypharmacy in elderly patients is very important. Collaboration between the medical profession needs to be done to evaluate the best treatment outcomes in elderly patients. Elderly patients with multiple diseases, it may get more types of drugs in polypharmacy, and potentially increase the inappropriate prescription drugs, and contributes to ADEs, ADRs, and duration of hospitalization.

Table 4: The impact of polypharmacy and PIMs among elderly

\begin{tabular}{|c|c|c|c|c|}
\hline Country, period & $\begin{array}{l}\text { Method of research; number of samples; } \\
\text { number of drugs }\end{array}$ & $\begin{array}{l}\text { Tools of PIM } \\
\text { evaluation }\end{array}$ & Result & References \\
\hline $\begin{array}{l}\text { January and } \\
\text { December 2012, } \\
\text { Italy }\end{array}$ & $\begin{array}{l}\text { The retrospective observational of } \\
1027 \text { patients aged } \geq 65 \text { years. The mean of } \\
\text { comorbidities was } 2.96 \pm 1.286 \text {, and prevalence } \\
\text { of polypharmacy was } 85 \%\end{array}$ & $\begin{array}{l}\text { The } 2012 \text { Beers } \\
\text { criteria, STOPP } \\
\text { criteria, IPET } \\
\text { criteria }\end{array}$ & $\begin{array}{l}\text { An aging can lead to an increasing } \\
\text { of polypharmacy. The comorbidity } \\
\text { affects the level of PIMs so that the } \\
\text { increasing of PIMs number will } \\
\text { occur the increasing hospitalization }\end{array}$ & [38] \\
\hline $\begin{array}{l}\text { October-December } \\
\text { 2005, Sweden }\end{array}$ & $\begin{array}{l}\text { The cross-sectional design of } 731,105 \text { older } \\
\text { people aged } \geq 75 \text { years. The mean number of }\end{array}$ & Sjoqvist system & $\begin{array}{l}\text { The multi-dose use can more } \\
\text { exposed to potential IDU }\end{array}$ & [37] \\
\hline
\end{tabular}

The cross-sectional design of 89 patients aged $\geq 65$ years. The mean prevalence of polypharmacy was $6.4 \pm 3.4$

Singapore, 2004 A randomly selected of 454 patients elderly age $>65$ years. The mean prevalence of polypharmacy was 6.4

A period of 3 months, Austrian

A monocentric prospective cohort study from 543 patients. The mean number of drugs was $7.5 \pm 3.8$, unnecessary drugs were $36.3 \%$, drugs to avoid in $30.1 \%$, duplication in $7.6 \%$, wrong dosage in $23.4 \%$ and possible DDIs in $65.8 \%$. ADEs were identified in $17.8 \%$

July 2004 and June 2005, Israel

A retrospective observational of 1027 patients aged $\geq 65$ years. The mean of chronic disease was $6.3 \pm 2.6$, and prevalence of polypharmacy was $5.95 \pm 2.4$

Ireland in 2007

\section{A retrospective national population} study (n=338,801) using, PIPs 27.392 (8\%) were prescribed two and 10.103 (3\%) were prescribed three or more. PPIs at maximum therapeutic dosage for $>8$ weeks was prescribed PIMs (56.560, 17\%)

23 January and 13 The cohort of 2053 elderly patients aged February 2013, $\geq 65$ years, the average was $48.4 \%$ of patients Japan $\quad$ were defined as PIMs. The PIM-induced ADEs were $8 \%$ of patients
MMSE

Beers' criteria STOPP/START criteria, IPET

HCFA

Beers criteria

The prevalence of IP among elderly home care and the risk factors for IP were associated of polypharmacy and specific underlying medical conditions The prevalence of polypharmacy use and PIMs are high in nursing homes, thus more medication used may lead to significant ADRs and Dis

Polypharmacy, IP, and ADEs were highly prevalent in elderly. Risk factors for ADEs were female sex, poly-morbidity, renal dysfunction and inappropriate prescribing. To improve drug safety, appropriate prescribing might be more important than simply reducing the number of prescribed drugs No relationship was found between IPDs on discharge and age, sex, functional status, cognitive level, number of chronic diseases, and cause of admission

STOPP criteria Polypharmacy was strongly associated with PIP

"Beers Criteria: The Japanese V.2003"

The PIM prevalence associated with home health care was relatively high 
Table 4: (Continued)

\begin{tabular}{|c|c|c|c|c|}
\hline Country, period & $\begin{array}{l}\text { Method of research; number of samples; } \\
\text { number of drugs }\end{array}$ & $\begin{array}{l}\text { Tools of PIM } \\
\text { evaluation }\end{array}$ & Result & References \\
\hline September 2011, & A retrospectively of 200 patients of age & & Polypharmacy was identified & \multirow[t]{5}{*}{ [43] } \\
\hline December 2011, & $\geq 65$ years. The $88 \%$ received at least one PIM & \multirow{4}{*}{ STOPP } & as a risk factor for PIM use, and & \\
\hline May 2012 and July & at admission, and median number of PIMs & & so reducing the total number & \\
\hline 2012, Germany & received by the patients was 4 , ranging from & & of prescribed drugs might be a & \\
\hline & 0 (in $12 \%$ of patients) to 8 (in $1 \%$ of patients) & & starting point to reduce PIM use & \\
\hline In 2007, Germany & $\begin{array}{l}\text { A pseudonymized data of } 804.400 \text { patient } \\
\text { aged } \geq 65 \text { years. The older people } 25.0 \% \text { who } \\
\text { received at least one PIM. The mean number } \\
\text { of drugs was } 6.2 \text { (SD: } 4.8 \text { ) for women and } \\
5.6 \text { (SD: } 4.7 \text { ) for men }\end{array}$ & PRISCUS list & $\begin{array}{l}\text { A large number of the drugs were } \\
\text { prescribed four or more times in } \\
8.8 \% \text { of all older people, which } \\
\text { is an indication of long-term } \\
\text { treatment }\end{array}$ & {$[44]$} \\
\hline In 2010, Germany & $\begin{array}{l}\text { A retrospectively, for } 647073 \text { patients aged } \\
\geq 65 \text { years. The incidence of hospitalization was } \\
39.44 \% \text { cases }\end{array}$ & PRISCUS list & $\begin{array}{l}\text { PIMs are associated with high } \\
\text { rates of ADEs associated with } \\
\text { hospitalization }\end{array}$ & [45] \\
\hline January & The cohort 392337 ambulatory patients aged & \multirow[t]{2}{*}{ PRISCUS list } & The HRs calculation demonstrated & \multirow[t]{2}{*}{ [46] } \\
\hline 2010, Germany & $\begin{array}{l}\text { during the observation period, and } 47,470 \\
\text { of them occurred within } 180 \text { days post first } \\
\text { dispensing }\end{array}$ & & $\begin{array}{l}\text { PIM dispensing and subsequent } \\
\text { excess hospitalization }\end{array}$ & \\
\hline July to December & 141 patients aged $\geq 65$ years with Barthel scale & STOPP and Beers & The high frequency of PIM in & \multirow[t]{2}{*}{ [47] } \\
\hline 2012, Taiwan & $\begin{array}{l}\text { scores } \leq 60 \text { and a regular intake of medication } \\
\text { for chronic diseases }\end{array}$ & 2012 criteria & $\begin{array}{l}\text { disabled older patients with } \\
\text { chronic diseases, particularly those } \\
\text { prescribed } \geq 6 \text { medications }\end{array}$ & \\
\hline South India, & 120 patients aged $\geq 60$ years, & STOPP and Beers & Polypharmacy and inappropriate & [48] \\
\hline 2013-2014 & $\begin{array}{l}39 \text { patients }(32.5 \%) \text { received inappropriate } \\
\text { medication }\end{array}$ & 2012 criteria & $\begin{array}{l}\text { prescription showed a significant } \\
\text { proportion of geriatric patients }\end{array}$ & \\
\hline \multirow[t]{2}{*}{$\begin{array}{l}\text { Ethiopia, } \\
\text { 2011-2013 }\end{array}$} & $\begin{array}{l}\text { The retrospective study of } 1252 \text { patients, } \\
\text { aged } \geq 65 \text { years } 347(27.72 \%) \text { were received at }\end{array}$ & \multirow[t]{2}{*}{$\begin{array}{l}\text { Beers } \\
\text { criteria (2012) }\end{array}$} & $\begin{array}{l}\text { PIMs prescriptions for the elderly } \\
\text { population who come to the }\end{array}$ & \multirow[t]{2}{*}[49]{} \\
\hline & least one potentially inappropriate medication & & $\begin{array}{l}\text { Gondar University Hospital often } \\
\text { occur }\end{array}$ & \\
\hline
\end{tabular}

PIM: Potential inappropriate medications, PPO: Prescribing omissions, STOPP/START: The Screening Tool of Older Person's Prescriptions/Screening Tool to Alert doctors to Right Treatment, IPET: The Improving Prescribing in the Elderly Tool, IDU: Inappropriate drug use, IP: Inappropriate prescribing, HCFA: The Health care Financing Administration, FORTA: Fit fOR The Aged List, IPDs: Inappropriate prescription drugs, MMSE: The Mini-Mental State Exam, PIP: Potentially inappropriate prescribing, ADE: Adverse drug events, ADR: Adverse drug reactions, DI: Drug interactions, HR: Hazard ratios, SD: Standard deviation

\section{REFERENCES}

1. Minister of Health of the Republic of Indonesia. No. 79. On the Implementation in the Hospital Care of the Elderly; 2014. Available from: http://www.lshk.or.id/uu/PMK\%20No.\%2079\%20ttg\%20 Penyelenggaraan\%20Pelayanan\%20Geriatri\%20di\%20RS.pdf.

2. Indonesian Central Statistics Agency. Indonesia Population Projection; 2010-2035. Available from: http://www.bappenas.go.id/ files/5413/9148/4109/Proyeksi Penduduk Indonesia 2010-2035.pdf.

3. Mamun K, Lien CT, Goh-Tan CY, Ang WS. Polypharmacy and inappropriate medication use in Singapore nursing homes. Ann Acad Med Singapore 2004;33(1):49-52.

4. Koh Y, Kutty FB, Li SC. Drug-related problems in hospitalized patients on polypharmacy: The influence of age and gender. Ther Clin Risk Manag 2005;1(1):39-48.

5. Elliott RA, Booth JC. Problems with medicine use in older Australians : A review of recent literature. J Pharm Pract Res 2014;44:258-71.

6. Jetha S. Polypharmacy, the elderly, and deprescribing. Consult Pharm 2015;30(9):527-32.

7. Department of Health and Human Services USA. A Profile of Older Americans; 2015. Available from: https:/www.aoa.acl.gov/aging_ statistics/profile/2015/docs/2015-profile.pdf.

8. Thürmann PA. Ageing of the Population, Polypharmacy, Potentially Inappropriate Prescribing and Quality Indicators. In European Perspective in Rational and Individualized Drug Therapy in Older Patients and Ageism - Priorities for Next Decades. Press Company Prager-LD, Praha; 2016. p. 8-10. Available from: http://www. notoageism.com/wp-content/uploads/2015/05/e_Abstract-Book_ Prague-EU-COST-Action-Training-School.pdf.

9. United Nations. World Population Ageing; 2015. United Nations, New York; 2015. Available from: http://www.un.org/en/development/desa/ population/publications/pdf/ageing/WPA2015_Report.pdf.

10. Nobili A, Garattini S, Mannucci PM. Multiple diseases and polypharmacy in the elderly: Challenges for the internist of the third millennium. J Comorbidity 2011;1:28-44

11. Lavan AH, Gallagher PF, O'Mahony D. Methods to reduce prescribing errors in elderly patients with multimorbidity. Clin Interv Aging 2016;11:857-66.

12. Morley JE. Hormones and the aging process. J Am Geriatr Soc 2003;51 7 Suppl: S333-7.

13. Walston J, Hadley EC, Ferrucci L, Guralnik JM, Newman AB, Studenski SA, et al. Research agenda for frailty in older adults: Toward a better understanding of physiology and etiology: Summary from the American geriatrics society/national institute on aging research conference on frailty in older adults. J Am Geriatr Soc 2006;54(6):991-1001.

14. Sinclair AJ, Morley JE, Vellas B. Pathy's Principles and Practice of Geriatric Medicine. $5^{\text {th }}$ ed. Chichester: A John Wiley \& Sons, Ltd.; 2012.

15. McLean AJ, Le Couteur DG. Aging biology and geriatric clinical pharmacology. Pharmacol Rev 2004;56(2):163-84.

16. Wooten JM. Pharmacotherapy considerations in elderly adults. South Med J 2012;105(8):437-45.

17. Elsawy B, Higgins KE. The geriatric assessment. Am Fam Physician 2011;83(1):48-56.

18. Cassel CK, Leipzig R, Cohen, HJ, Larson EB, Meier DE, editors. Geriatric Medicine: An Evidence-Based Approach. $4^{\text {th }}$ ed. USA: Springer; 2003.

19. British Geriatrics Society. Comprehensive Geriatric Assessment; 2014. Available from: http://www.bgs.org.uk/cga-managing/resources/ campaigns/fit-for-frailty/frailty-cga.

20. Gupta M, Agarwal M. Understanding medication errors in the elderly. N Z Med J 2013;126(1385):62-70.

21. O'Connor MN, Gallagher P, O'Mahony D. Inappropriate prescribing: Criteria, detection and prevention. Drugs Aging 2012;29(6):437-52.

22. Davies EA, O'Mahony MS. Adverse drug reactions in special populations - The elderly. Br J Clin Pharmacol 2015;80(4):796-807.

23. Sato I, Akazawa M. Polypharmacy and adverse drug reactions in 
Japanese elderly taking antihypertensives: A retrospective database study. Drug Healthc Patient Saf 2013;5:143-50.

24. Schuler J, Dückelmann C, Beindl W, Prinz E, Michalski T, Pichler M. Polypharmacy and inappropriate prescribing in elderly internal-medicine patients in Austria. Wien Klin Wochenschr 2008;120(23-24):733-41.

25. Hanlon JT, Artz MB, Pieper CF, Lindblad CI, Sloane RJ, Ruby CM, et al. Inappropriate medication use among frail elderly inpatients. Ann Pharmacother 2004;38(1):9-14.

26. Milton JC, Hill-Smith I, Jackson SH. Prescribing for older people. BMJ 2008;336(7644):606-9.

27. Jayarama N, Sleeba SK, Prabhakar K. Adverse drug reactions in adults leading to emergency department visits. Int J Pharm Pharm Sci 2012;4 Suppl 4:642-6.

28. Teka F, Teklay G, Ayalew E, Teshome T. Potential drug - Drug interactions among elderly patients admitted to medical ward of Ayder Referral Hospital, Northern Ethiopia: A cross sectional study. BMC Res Notes 2016;9(1):431

29. Obreli Neto PR, Nobili A, de Lyra DP Jr, Pilger D, Guidoni CM, de Oliveira Baldoni A, et al. Incidence and predictors of adverse drug reactions caused by drug-drug interactions in elderly outpatients: A prospective cohort study. J Pharm Pharm Sci 2012;15(2):332-43.

30. Calderón-Larrañaga A, Poblador-Plou B, González-Rubio F, Gimeno-Feliu LA, Abad-Díez JM, Prados-Torres A. Multimorbidity, polypharmacy, referrals, and adverse drug events: Are we doing things well? Br J Gen Pract 2012;62(605):e821-6.

31. de Lyra DP, Kheir N, Abriata JP, da Rocha CE, Dos Santos CB, Pelá IR. Impact of pharmaceutical care interventions in the identification and resolution of drug-related problems and on quality of life in a group of elderly outpatients in Ribeirão Preto (SP), Brazil. Ther Clin Risk Manag 2007;3(6):989-98.

32. Al-Hamid A, Ghaleb M, Aljadhey H, A slanpour Z. A systematic review of hospitalization resulting from medicine-related problems in adult patients. Br J Clin Pharmacol 2014;78(2):202-17.

33. Nivya K, Sri Sai Kiran V, Ragoo N, Jayaprakash B, Sonal Sekhar M. Systemic review on drug related hospital admissions - A PubMed based search. Saudi Pharm J 2015;23(1):1-8.

34. Shah BM, Hajjar ER. Polypharmacy, adverse drug reactions, and geriatric syndromes. Clin Geriatr Med 2012;28(2):173-86.

35. Mangoni AA, Jackson SH. Age-related changes in pharmacokinetics and pharmacodynamics: Basic principles and practical applications. $\mathrm{Br}$ J Clin Pharmacol 2004;57(1):6-14.

36. Hobson M. Medications in older patients. West J Med 1992;157(5):539-43.

37. Johnell K, Fastbom J. Multi-dose drug dispensing and inappropriate drug use: A nationwide register-based study of over 700,000 elderly. Scand J Prim Health Care 2008;26(2):86-91.
38. Di Giorgio C, Provenzani A, Polidori P. Potentially inappropriate drug prescribing in elderly hospitalized patients: An analysis and comparison of explicit criteria. Int J Clin Pharm 2016;38(2):462-8.

39. Hamano J, Tokuda Y. Inappropriate prescribing among elderly home care patients in Japan: Prevalence and risk factors. J Prim Care Community Health 2014;5(2):90-6.

40. Mansur N, Weiss A, Beloosesky Y. Is there an association between inappropriate prescription drug use and adherence in discharged elderly patients? Ann Pharmacother 2009;43:177-84.

41. Cahir C, Fahey T, Teeling M, Teljeur C, Feely J, Bennett K. Potentially inappropriate prescribing and cost outcomes for older people: A national population study. Br J Clin Pharmacol 2010;69(5):543-52.

42. Onda M, Imai H, Takada Y, Fujii S, Shono T, Nanaumi Y. Identification and prevalence of adverse drug events caused by potentially inappropriate medication in homebound elderly patients: A retrospective study using a nationwide survey in Japan. BMJ Open 2015;5(8):e007581.

43. Wickop B, Härterich S, Sommer C, Daubmann A, Baehr M, Langebrake $\mathrm{C}$, et al. Potentially inappropriate medication use in multimorbid elderly inpatients: Differences between the FORTA, PRISCUS and STOPP Ratings. Drugs Real World Outcomes 2016;3(3):317-25

44. Amann U, Schmedt N, Garbe E: Prescribing of potentially inappropriate medications for the elderly: An analysis based on the PRISCUS list. Dtsch Arztebl Int 2012;109(5):69-75.

45. Henschel F, Redaelli M, Siegel M, Stock S. Correlation of incident potentially inappropriate medication prescriptions and hospitalization: An analysis based on the PRISCUS list. Drugs Real World Outcomes 2015;2(3):249-59.

46. Endres HG, Kaufmann-Kolle P, Steeb V, Bauer E, Böttner C, Thürmann P. Association between Potentially Inappropriate Medication (PIM) use and risk of hospitalization in Older adults: An observational study based on routine data comparing PIM use with use of PIM alternatives. PLoS One 2016;11(2):e0146811.

47. Yang PJ, Lee YT, Tzeng SL, Lee HC, Tsai CF, Chen CC, et al. Potentially inappropriate prescribing in disabled older patients with chronic diseases: A screening tool of older persons' potentially inappropriate prescriptions versus beers 2012 criteria. Med Princ Pract 2015;24(6):565-70.

48. Chowta MN, Adhikari PM, Raj S, Laxman M, Kariappa A, George J, et al. Evaluation of appropriateness of prescription and polypharmacy in the geriatric population: A cross sectional study at a comprehensive geriatric clinic in a tertiary care hospital. Int $\mathrm{J}$ Pharm Pharm Sci 2016;8(3):119-23.

49. Mekonnen AB, Bhagavathula AS. Inappropriate medication use in the elderly population attending Gondar University hospital: A preliminary assessment. Int J Pharm Pharm Sci 2014;6(10):540-3 